\title{
Psychoeducational support group to the resilience of caregivers of chronic kidney disease patients undergoing hemodialysis
}

\author{
Nadya Ariyani Hasanah Nuriyyatiningrum, ${ }^{1 *}$ Ahmad Gimmy Prathama Siswadi, ${ }^{2}$ \\ Achmad Djunaidi, ${ }^{2}$ Quadri Mojeed Akorede ${ }^{3}$ \\ ${ }^{1}$ Faculty of Psychology and Health, Universitas Islam Negeri Walisongo, Semarang - Indonesia; \\ ${ }^{2}$ Faculty of Psychology, Universitas Padjadjaran, Bandung - Indonesia; ${ }^{3}$ Harmony Concepts Educational \\ Solutions, Effurun, Delta State - Nigeria
}

\begin{abstract}
Making a resilient caregiver is important; in addition to lack of preparation, they are not adequately supported. Psychoeducational support groups can provide the necessary education about the conditions they are about to confront and create the sources of social support that will enable and fortify them when dealing with difficult conditions. This research aimed to understand the effect of a psychoeducational support group on caregivers' resilience of chronic kidney disease patients undergoing hemodialysis. Five subjects were used in this case study, which employed mixed methods using a concurrent embedded strategy that used primary quantitative data. The qualitative data analysis used thematic analysis, while the quantitative data analysis used Wilcox signed ranks test. Quantitative data analysis showed a p-value of .892, which led the researcher to conclude no differences between the pre and post resilience scores. Qualitative primary data analysis revealed that psychoeducational support group has a positive effect on caregivers' resilience. Besides, this research discovered that a psychoeducational support group can significantly increase the perception of caring ability and ameliorate the difficulties in taking care of patients.
\end{abstract}

Keywords: psychoeducational support group; resilience; caregiver; chronic kidney disease

Abstrak: Menjadi caregiver yang resilien merupakan hal yang penting, mengingat tidak semua caregiver siap berperan dan kurang mendapat dukungan. Psychoeducational support group dapat memberikan edukasi mengenai kondisi yang dihadapi sekaligus menciptakan sumber dukungan sosial bagi anggotanya, sehingga diharapkan caregiver dapat beradaptasi ketika menghadapi kondisi sulit. Tujuan penelitian ini untuk melihat efek psychoeducational support group terhadap resiliensi caregiver pasien chronic kidney disease yang menjalani hemodialisis. Partisipan berjumlah 5 orang. Penelitian ini merupakan studi kasus dengan mixed method menggunakan concurrent embedded strategy yang menggunakan data primer kualitatif. Data kualitatif dianalisis menggunakan Thematic Analysis. Data kuantitatif dianalisis menggunakan uji Wilcoxon Signed Ranks. Data kuantitatif menunjukkan $p$-value sebesar 0,892, sehingga secara kuantitatif tidak terdapat perbedaan skor antara pre dengan post test resiliensi. Namun berdasarkan hasil data primer kualitatif disimpulkan bahwa psychoeducational support group memberikan efek positif pada peningkatan resiliensi para caregiver. Secara lebih lanjut penelitian ini mendapatkan bahwa psychoeducational support group meningkatkan secara signifikan persepsi terhadap kemampuan merawat dan menurunkan tingkat kesulitan merawat pasien.

Kata Kunci: psychoeducational support group; resiliensi; caregiver; chronic kidney disease

\footnotetext{
*Corresponding Author: Nadya Ariyani Hasanah Nuriyyatiningrum (nadya.ariyanihn@walisongo.ac.id), Faculty of Psychology, Universitas Islam Negeri Walisongo Semarang, Jl. Prof. Dr. HAMKA, Km. 2 Ngaliyan Semarang 50185-Indonesia.
} 


\section{Introduction}

Chronic kidney disease is a clinical syndrome caused by a decrease in kidney function that is chronic, progressive, persistent, and irreversible (Mansjoer, 2000). Indonesian Renal Registry (2014) reported that the number of chronic kidney patients actively undergoing treatment kept increasing. The highest number of patients, both new and active, was found in West Java (who amounted to 3,358 individuals).

Hemodialysis is one of the therapeutic procedures that can be implemented to replace the function of a declining kidney by means of a machine that takes over kidney's function to remove toxic substances from the body's (Smeltzer \& Bare, 2003), and it is the most widely used type of therapy, with a percentage of $82.4 \%$ (Indonesian Renal Registry, 2014). Hemodialysis is usually done 3 times a week for at least 3-4 hours each. It must be carried out constantly throughout patients' life or until a successful kidney transplant is performed (Smeltzer \& Bare, 2003).

Routine hemodialysis therapy will bring an effect on the patient. Nevid, Rathus, and Greene (2005) state that an investigation of the relationship between stress and disease can be done by considering life changes related to physical health. The disease can psychologically and physically affect patient's condition and put them at the mercy of other people, especially the caregivers.

The Family Caregiver Alliance (2009) states that 'caregivers' refer to patients' children, wives, husbands, grandchildren, nieces/nephews, and friends. Kahn (2005) explains that a caregiver becomes the center for providing resources, support, and various other essential aspects to fulfill the patient's needs. Nuriyyatiningrum and
Usri (2017) state that caregivers may face many physical and psychological problems. Sleep disorders, delayed personal activities, financial problems, discomfort, sadness, rout, incompetence, downturn, disappointment, shame, as well as and with the patient are the things that a caregiver. Data from the Family Caregiver Alliance (2009) states that a caregiver's various activities also impact their physical and emotional health.

Walker (1996, 1997, in Merrill, 1997) states that an individual's motivation to become a caregiver is based on his/her expectation or an existing external normative structure. The National Alliance for Caregiving (NAC) and the AARP Public Policy Institute within the Family Caregiver Alliance (2009) explain that the majority of caregivers who are not prepared to carry out the caring role are lacking even psychological or material support from their surroundings.

Such condition is very apparent among informal caregivers (who do not get paid for their role). Researchers saw that caregivers need various support based on the initial interviews, including emotional, informational, and tangible supports. In the study conducted by NavaieWaliser, Feldman, Gouls, Levine, Kuerbis, and Donelan (2002) on 1,002 informal caregivers in the United States, it was found that more than a third of caregivers continued to provide intensive care for others while their health deteriorated.

Sharma, Chakrabarti, and Grover (2016), in their research, found that female caregivers experienced greater tension because of the role, thus making health problems more frequent. They lacked a positive outlook on life, and they need greater external support. Women are identified as having a greater emotional and social connection to patients and a greater sense of obligation to care for them. 
The condition in caregiving situation that is full of challenges requires the caregivers to have good resilience. According to Greeff (2005), resilience is a form of adaptation that brings success in facing risks and difficulties. Resilience can be defined as the capacity that makes an individual stronger and survive in facing many stressors (Bukhori, Hassan, Hadjar and Hidayah, 2017) defines resilience as the ability to develop, mature, and continue to move forward with confidence whatever the circumstances. McCurry (2006) explains that caregivers' resilience is how to survive and grow and develop in an environment that continually changes and often differs from predictions about themselves and about their relationships with patients. The results of the study done by Harmell, Chattilion, Roepka, and Mausbach (2011) showed that the higher the personal mastery and self-efficacy caregivers have, the better they can protect their health. Thus, it is recommended to conduct further research on interventions for caregivers, focusing on increasing their resilience and benefiting their health.

Schoon (2006) explains that there are several protective factors for resilience. One of them is the broader social context that can function as the primary source of support. American Psychological Association (2016) (states that the main factor in resilience is caring and supportive relationships inside and outside the family that can create affection and trust, provide role models, and offer encouragement and assurance to improve one's resilience.

Nuriyyatiningrum and Usri (2017) state that internal and external factors can support caregivers when they try to overcome various caregiving problems. The internal factors are their understanding of the patient's condition, the initiative to seek all information about chronic kidney disease, and the presence of spirituality. The forms of spirituality in caregivers include the belief that God will help as long as they are submissive, the thought that religion does not allow its believers to feel burdened yet encourage them to pray rather than complain about circumstances, the belief that behind the difficulties there is a certain wisdom, gratefulness for the difficult circumstances, the thought that the patient is chosen by God's to stand His test, the belief that pain is a sin remover. The external factors include relationships with patients, family, and others in the surroundings. Relationships with other people could be in the form of a specific community, which is advantageous for caregivers because they can have a place to share their stories, get reinforcement and support, and also models of learning from others. It shows that understanding the self and situation and the relationship with others are essential issues that merit scholarly discussion.

Psychoeducational support group, one type of psychoeducation interventions is expected to meet an individual's need for understanding and support that they lack in the initial period of caregiving. Schulz (2000) explains the potential intervention strategies that can be taken for caregivers. It was explained that from several stages of a disease, the caregiver could be given intervention in the form of education and a support group at an early stage. Following the initial data collection results, all caregivers voiced their need to communicate with their fellow caregivers. These activities are necessary because caregivers need to share information about how care can be given based on their individual experiences. This can be feedback and motivation for other caregivers.

Psychoeducational support groups have been conducted in several studies. The psycho- 
educational support group conducted by Lefley (2009) on patients who had serious mental illness revealed that a group has the power to influence its members in overcoming fear, accepting work according to their capabilities, and improving their lives. Posner, Wilson, Kral, Lander and Mcllwraith (1992) conducted a psychoeducational support family of patients with schizophrenia, showing that they had more knowledge than the control group. Chien (2008) conducted a similar study with the results that improved patients' function and lowered the hospital's frequency of treatment. Hébert, Levesque, Vezina, Lavoie, Cudharme, Gendron, Preville, Voyer, and Dubois (2003) also state that by providing a group psychoeducation program to caregivers of patients with dementia can reduce the reaction of patients' behavioural problems. Based on this fact, psychoeducation and group support in the psychoeducational support group can affect both the caregiver and the patient. The various roles require the ability to adapt to difficult circumstances. In Indonesia, psychoeducational support groups for the caregivers of chronic kidney disease patients undergoing hemodialysis are not available. Accordingly, the researchers were interested in creating an intervention in the form of a psychoeducational support group that can forge attentive and supportive relationships outside the families of caregivers of chronic kidney disease patients undergoing hemodialysis. Psychoeducational support groups are expected to increase caregivers' resilience to become an effective source of support for the patients. Consequently, the patient's condition will become more stable.

Thus, the underlying research question was: How the psychoeducational support group affects the resilience of a caregiver of chronic kidney disease patients undergoing hemodialysis. The study aime to determine the effect of psychoeducational support groups on the resilience of caregivers of chronic kidney disease patients undergoing hemodialysis.

\section{Method}

This research was a case study with a concurrent embedded strategy of mixed methods that examined a psychoeducational support group's effect on an individual. The researchers used concurrent embedded strategy, with qualitative data as the primary data, as shown in Figure 1. We used a quasi-experiment with onegroup pretest-posttest design with the pattern as shown in Figure 2.

\section{Variables of the Study}

The independent variable in this study was the psychoeducational support group. It was a group consisting of individuals who had similar characteristics to play a role in providing support in educational components and emotional support systems in 3 specific sessions and specific themes.

Each session's implementation involved the presentation of materials and group discussion to meet the education component and emotional support among them. We chose themes that deal with information about chronic kidney disease (Material 1), resilience (Material 2), and donations (Material 3). The themes were chosen based on the analysis of the participants' needs obtained through pre-session.

The dependent variable in this study was resilience. A resilient individual is defined as every individual who has personal security, a strong belief in their abilities, and meaning and purpose in carrying out their roles. Personal safety is derived from the view that the surrounding 
Figure 1

Concurrent Embedded Strategy

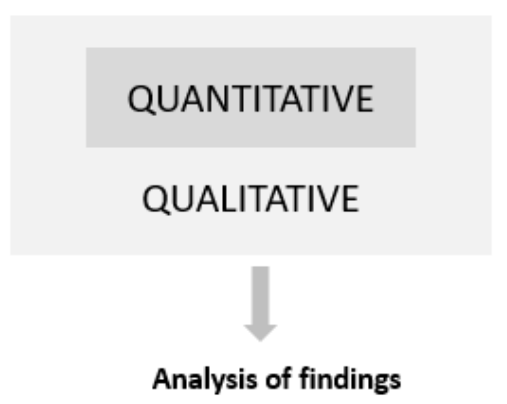

Figure 2

One-Group Pretest-Posttest Design

\section{Measurement $\left(O_{1}\right)$}

\section{Manipulation $(X)$}

\section{Measurement $\left(\mathrm{O}_{2}\right)$}

people's encouragement to an individual makes them feel safe and comfortable while performing their duties. Strong confidence about one's ability is obtained from the individuals' belief that they can help others. While the meaning and purpose are obtained from the existence of a deep meaning and ownership of goals directed in carrying out the role.

\section{Participants of the Study}

The study used a purposive sampling technique. To get the research participants, we collaborated with $\mathrm{X}$ hospital in Bandung to obtain information related to patients fitting the study's participants' criteria. They were female individuals who became the main caregivers of chronic kidney disease patients undergoing hemodialysis for less than 1 year. They were considered to be fresh caregivers who had realized the difficulty of the role. They were female because of the assumption that women can make a greater impact on caregiving. They should be at least 18 years old, a periode of life that marks the beginning of adulthood. They should participate in all sessions of the study on a voluntary basis. The remaining number of participants was 5 out of 7.

\section{Site of the Study}

This study was done in a hemodialysis unitof $\mathrm{X}$ hospital located in Bandung, West Java, Indonesia. The three sessions for group 1 were conducted in a room provided by the hospital. Group 2 attended sessions 2 and 3 only in the same room, and the session 1 was conducted in an office room because of an emergency situation; a patient was rushed to the hemodialysis unit. 


\section{Measuring Instruments of the Study}

The measurements were carried out using interview instruments and scales. The interview guide and resilience scale were derived from Hooper's resilience (2012), which includes 3 elements of resilience, namely personal security, strong self-belief, and meaning and purpose. The interviews were conducted using the semi-open interview method, which was then analysed using a thematic analysis of the deductive (theoretical) method. The resilience scale used had passed the testing phase by researchers using the Smart PLS 3 programs. The trial was conducted on 71 people using online media. The result showed that each aspect's composite reliability number was more significant than .7 with.939 for the personal security aspect, .940 for the strong self-belief aspect, and .918 for the meaning and purpose. Thus, the resilience scale was reliable. The Average Variance Extracted (AVE) rate of each aspect was higher .5, (.544 to be precise) for the personal security aspect, .550 for the strong selfbelief aspect, and .509 for the meaning and purpose aspect. Cross-loading results revealed that the loading of all items in the original aspect was greater than cross-loading in other aspects. Thus, the resilience scale could be valid. After the trial, the scale items were reduced to 37 from the 44 statements we tested. This study counted two paired samples; the test on the same sample was done before and after the implementation of the psychoeducational support group. Given the small number of the participants, the data were processed and analyzed using the Wilcoxon Signed Ranks test. In addition, the researchers also used supporting data obtained from observations using an open format, evaluation of each session with a knowledge-testing procedure of fixed response items, and scaling of the participants' difficulties and abilities in caring the patients.

\section{Results}

Table 1 illustrates the research participants and their respective patients. Psychoeducational support group intervention was done three times for each group. The participants were divided into two groups (one group of $\mathrm{P}_{1}, \mathrm{P}_{2}$, and $\mathrm{P}_{3}$, and the other group of $\mathrm{P}_{4}$ and $\mathrm{P}_{5}$ ) because it had to be adapted to each patient's hemodialysis schedule. The intervention was done once a week except for the group 2's sessions 3, which was 2 weeks apart because both participants could not attend on the day originally scheduled.

Based on the results of Wilcoxon Signed Ranks test, $\mathrm{Z}$ value was -.135 with $p$ value (asymp sig 2 tailed) of .892, which was higher than 10 so that it could be concluded that quantitatively there was no difference score of resilience between the pretest and the post-test $\left(\mathrm{H}_{1}\right.$ rejected).

Based on the Wilcoxon Signed Ranks test results, the $\mathrm{Z}$ value obtained for scaling the level of difficulty in treatment was -2.060 with a $p$ value (asymp sig 2 tailed) of .039, which was less than .10 , so it could be concluded that there were different scores between pre-tests and post-test scaling of the level of difficulty in caring $\left(\mathrm{H}_{1}\right.$ accepted). It appeared that the scaling of the participants' difficulties of care giving decreased following the intervention. Besides, regarding the scaling of the caregiving ability level, the $Z$ value was -1.841 with $\mathrm{p}$ value (asymp sig 2 tailed) of .066 , which was less than .10 , so it could be concluded that there were significantly different scores between pre-test and post-test $\left(\mathrm{H}_{1}\right.$ accepted). It appeared that the scaling of the caregiving ability of participants increased following the intervention. 


\section{Participant 1}

Based on the aspects of resilience, participants $1\left(\mathrm{P}_{1}\right)$ seemed to have fairly good aspects of personal security and the meaning and purpose.
But in the aspect of strong self-belief, she was deficient. Apart from the qualitative data,

\section{Table 1}

Participants of the Study

\begin{tabular}{|c|c|c|c|c|c|}
\hline Participant & $\mathrm{P} 1(\mathrm{SP})$ & P2 (YKM) & P3 $(\mathrm{N})$ & P4 (TA) & P5 (ENH) \\
\hline Age & 48 & 59 & 54 & 47 & 45 \\
\hline Religion & Islam & Islam & Islam & Islam & Islam \\
\hline Ethnicity & Javanese & Sundanese & Sundanese & Sundanese & Sundanese \\
\hline Education & High School & $\begin{array}{l}\text { Associate } \\
\text { Degree }\end{array}$ & High School & $\begin{array}{l}\text { Elementary } \\
\text { School }\end{array}$ & $\begin{array}{l}\text { Bachelor's } \\
\text { Degree }\end{array}$ \\
\hline Occupation & Housewife & Housewife & $\begin{array}{l}\text { Entrepreneur } \\
\text { (Preschool } \\
\text { educator) }\end{array}$ & Housewife & $\begin{array}{l}\text { Secondary } \\
\text { School teacher }\end{array}$ \\
\hline Number of Children & 2 & 2 & 6 & 4 & 3 \\
\hline $\begin{array}{l}\text { Relation with the } \\
\text { patient }\end{array}$ & Wife & Wife & Wife & Mother & Wife \\
\hline $\begin{array}{l}\text { Length ofCaring } \\
\text { (Month) }\end{array}$ & 8 & 6 & 6 & 8 & 3 \\
\hline Physical condition & $\begin{array}{l}\text { Many } \\
\text { activities, } \\
\text { very tired, } \\
\text { once got sick }\end{array}$ & $\begin{array}{l}\text { Outside } \\
\text { home } \\
\text { business, } \\
\text { tired but not } \\
\text { felt as a } \\
\text { burden }\end{array}$ & $\begin{array}{l}\text { Sick after the } \\
\text { patient could } \\
\text { leave } \\
\text { hospital, cold, } \\
\text { eat less, sleep } \\
\text { deprivation }\end{array}$ & $\begin{array}{l}\text { Tired and } \\
\text { wanting to } \\
\text { rest, less } \\
\text { time to } \\
\text { sleep }\end{array}$ & $\begin{array}{l}\text { Tired, time } \\
\text { divided, less time } \\
\text { to sleep at night, } \\
\text { uncontrolled } \\
\text { eating pattern, } \\
\text { gastric ulcer } \\
\text { recurring, back } \\
\text { pain }\end{array}$ \\
\hline $\begin{array}{l}\text { Psychological } \\
\text { condition }\end{array}$ & $\begin{array}{l}\text { Sad, upset, } \\
\text { unable to go } \\
\text { anywhere } \\
\text { and must } \\
\text { always be } \\
\text { ready to stay } \\
\text { close to the } \\
\text { patient, } \\
\text { happy } \\
\text { because of } \\
\text { the chance to } \\
\text { take care of } \\
\text { husband }\end{array}$ & $\begin{array}{l}\text { Sad, worried, } \\
\text { still enjoying, } \\
\text { and grateful }\end{array}$ & $\begin{array}{l}\text { Upset if the } \\
\text { patient was } \\
\text { fussy, } \\
\text { confused, } \\
\text { afraid of } \\
\text { making } \\
\text { mistake, sad, } \\
\text { worried if } \\
\text { leaving the } \\
\text { house }\end{array}$ & $\begin{array}{l}\text { Poor, sad, } \\
\text { worried, } \\
\text { restless, } \\
\text { upset, } \\
\text { heartache }\end{array}$ & $\begin{array}{l}\text { Sad, anxious, } \\
\text { worried, } \\
\text { irritated, } \\
\text { reluctant to go } \\
\text { home, angry, } \\
\text { difficult to } \\
\text { manage the } \\
\text { patient's eating, } \\
\text { consoled when } \\
\text { interacting with } \\
\text { students }\end{array}$ \\
\hline
\end{tabular}


N. A. H. Nuriyyatiningrum, A. G. P. Siswadi, A. Djunaidi, Q. M. Akorede

Table 2

The Condition of the Patients the Participants Took Care of

\begin{tabular}{|c|c|c|c|c|c|}
\hline $\begin{array}{l}\text { Patient's } \\
\text { Condition }\end{array}$ & $\mathrm{P}_{1}(\mathrm{SP})$ & $\mathrm{P}_{2}(\mathrm{YKM})$ & $\mathrm{P}_{3}(\mathrm{~N})$ & $\mathrm{P}_{4}$ (TA) & $\mathrm{P}_{5}(\mathrm{ENH})$ \\
\hline Age & 50 & 64 & 62 & 29 & 43 \\
\hline Occupation & Soldier & Researcher & $\begin{array}{l}\text { Head of a } \\
\text { foundation }\end{array}$ & $\begin{array}{l}- \\
\text { (was a } \\
\text { merchant) }\end{array}$ & $\begin{array}{l}\text { - } \\
\text { (was a service } \\
\text { company } \\
\text { employee) }\end{array}$ \\
\hline Physical & $\begin{array}{l}\text { having } \\
\text { cataracts, } \\
\text { impaired } \\
\text { vision }\end{array}$ & $\begin{array}{l}\text { Walking } \\
\text { slowly }\end{array}$ & $\begin{array}{l}\text { not strong } \\
\text { enough to walk } \\
\text { far, get tired } \\
\text { easily, often go } \\
\text { to the ER or } \\
\text { advance the } \\
\text { schedule of } \\
\text { receiving HD }\end{array}$ & $\begin{array}{l}\text { Unable to } \\
\text { walk far, } \\
\text { easily tired, } \\
\text { often } \\
\text { experience } \\
\text { shortness, } \\
\text { often taken to } \\
\text { the ER }\end{array}$ & $\begin{array}{l}\text { Often bloated and } \\
\text { back pain. }\end{array}$ \\
\hline Psychological & $\begin{array}{l}\text { Got upset } \\
\text { frequently }\end{array}$ & $\begin{array}{l}\text { Becoming } \\
\text { more silent }\end{array}$ & $\begin{array}{l}\text { Fussy, getting } \\
\text { impatient }\end{array}$ & $\begin{array}{l}\text { No special } \\
\text { psychological } \\
\text { condition }\end{array}$ & $\begin{array}{l}\text { often uttering } \\
\text { words of despair, } \\
\text { his father died } 10 \\
\text { months before } \\
\text { the patient was } \\
\text { diagnosed with } \\
\text { the same illness }\end{array}$ \\
\hline
\end{tabular}

Table 3

The Results of Pre-Test and Post-Test Measuring of the Resilience Aspects

\begin{tabular}{clcccc}
\hline $\mathrm{P}$ & Aspect & Pre-Test & $\begin{array}{c}\text { Mean } \\
\text { (Category) }\end{array}$ & Post-Test & $\begin{array}{c}\text { Mean } \\
\text { (Category) }\end{array}$ \\
\hline $\mathrm{P}_{1}$ & $P S$ & 43 & $3.3(\mathrm{~T})$ & 40 & $3.07(\mathrm{~T})$ \\
& $S S B$ & 38 & $2.9(\mathrm{~S})$ & 40 & $3.07(\mathrm{~T})$ \\
& $M P$ & 37 & $3.7(\mathrm{~T})$ & 39 & $3.9(\mathrm{~T})$ \\
$\mathrm{P}_{2}$ & $P S$ & 41 & $3.15(\mathrm{~T})$ & 40 & $3.07(\mathrm{~T})$ \\
& $S S B$ & 41 & $3.15(\mathrm{~T})$ & 37 & $2.85(\mathrm{~S})$ \\
& $M P$ & 42 & $4.2(\mathrm{~T})$ & 33 & $3.3(\mathrm{~S})$ \\
$\mathrm{P}_{3}$ & $P S$ & 42 & $3.23(\mathrm{~T})$ & 44 & $3.38(\mathrm{~T})$ \\
& $S S B$ & 38 & $2.92(\mathrm{~S})$ & 45 & $3.46(\mathrm{~T})$ \\
& $M P$ & 34 & $3.4(\mathrm{~T})$ & 47 & $3.7(\mathrm{~T})$ \\
$\mathrm{P}_{4}$ & $P S$ & 48 & $3.69(\mathrm{~T})$ & 46 & $3.54(\mathrm{~T})$ \\
& $S S B$ & 47 & $3.61(\mathrm{~T})$ & 44 & $3.38(\mathrm{~T})$ \\
& $M P$ & 42 & $4.2(\mathrm{~T})$ & 43 & $4.3(\mathrm{~T})$ \\
$\mathrm{P}_{5}$ & $P S$ & 48 & $3.69(\mathrm{~T})$ & 49 & $3.76(\mathrm{~T})$ \\
& $S S B$ & 39 & $3(\mathrm{~S})$ & 39 & $3(\mathrm{~S})$ \\
& $M P$ & 40 & $4.0(\mathrm{~T})$ & 40 & $4.0(\mathrm{~T})$ \\
\hline \multirow{4}{*}{} & & & & &
\end{tabular}


Table 4

The Results of Scaling for the Difficulty in Caring and the Assessment of Caring Ability

\begin{tabular}{lcccc}
\hline $\mathrm{P}$ & $\begin{array}{c}\text { Difficulty } \\
\text { Pre }\end{array}$ & Difficulty Post & Ability Pre & Ability Post \\
\hline $\mathrm{P}_{1}$ & 7 & 5 & 6 & 8 \\
$\mathrm{P}_{2}$ & 4 & 2 & 9 & 9 \\
$\mathrm{P}_{3}$ & 8 & 6 & 4 & 10 \\
$\mathrm{P}_{2}$ & 9 & 5 & 7 & 9 \\
$\mathrm{P}_{5}$ & 8 & 3 & 7 & 8 \\
\hline
\end{tabular}

the quantitative data also showed the same results. The average score of $\mathrm{P}_{1}$ 's strong self-belief was lower than the other aspects' scores. She did not seem too confident about her ability in caregiving. She stated that other people declared themselves capable, but she thought she scored 6 (out of 10) because she felt she still needed someone else to help her.

$\mathrm{P}_{1}$ could obtain a cumulative score of 23 out of 30 on the knowledge test. She received informational support through materials provided from the speaker and other participants. Various information had an effect on the increase of her strong self-belief. She stated that her ability and knowledge increased. She also became more enthusiastic to try to perform other tasks of caregiving. For example, she wanted to practice using a tens meter because she thought that she must be independent in taking care of the patients. She stated that the new information made her able to self-assess her ability on the scale of 8, (previously she scored 6 at pre-test). This was in line with the quantitative data that indicated an increase of 2 points in strong selfbelief. Regarding the changes in the patients' emotions in the post-test interview, she could find the possible causes for the changes in their behaviours in the last 3 days. She tried to use ABC techniques to solve problems that occurred in the patients at that time. The $\mathrm{ABC}$ technique gave her the idea that ' $\mathrm{A}$ ' is an activator or trigger of a problem, ' $\mathrm{B}$ ' is a behavioural concern, and ' $\mathrm{C}$ ' is a direct consequence or caregiver's response to a patient's behaviour. $B$ becomes very important to do because what often happens is that $A$ jumps to C without going through the process of $B$. Through the new technical information, she stated that she could correct the errors in treating the patients.

Based on the aspect of personal security, $\mathrm{P}_{1}$ stated that people's attitude had already made her feel comfortable. There were always neighbours who were willing to drop off, families paying attention, and husband's officemates giving their full support. Her participation in the intervention made her feel happy because he could laugh. During the intervention, other participants could also respond to calm her worry about whether the patient would return the favor (i.e., take care of her) when she got sick. It showed the presence of emotional support from other participants to her. It affected the increase of her security after being given an intervention. $\mathrm{P}_{1}$ stated that she found that she had more sisters because she received additional information and communication with other participants. 
Based on the aspect of meaning and purpose, P1's understanding increased as she realized that there was a blessing behind her situation and got deeper meaning that she was indeed the person her husband needed. She was grateful to God. Her purpose also changed. Initially, she only wanted to make the patient get healthy. Then she wished that the patient could do as she did to him one day, specifically taking care of her if she gets sick. As a result of the intervention, her assessment of her success in taking care of the patient changed. She initially stated that she had not successfully treated the patient. Because she considered she would have been successful only when the patient had already recovered and had not had to perform hemodialysis anymore. After the standard intervention, her assessment of success turned out to be more realistic. She finally rated herself successful at the score of $6 / 7$ because the patient had become more enthusiastic about carrying out hemodialysis and been quite able to follow the doctor's advice. This was in line with the increased score of the resilience scale to 119 . Therefore, it could be concluded that the intervention of psychoeducational support groups affected increasing the resilience of participant 1.

\section{Participant 2}

Prior to the psychoeducational support group intervention, participant $2\left(\mathrm{P}_{2}\right)$ appeared to have the aspects of strong self-belief, personal security, and meaning and purpose. According to her, treating the patient was not a hard thing to do. She was reinforced by the fact that the patient did not burden her because of being an independent person.

Throughout the intervention, $\mathrm{P}_{2}$ became more aware of chronic kidney disease, various conditions that could be experienced by the patient, how to treat and deal with the patient as well as various new solutions. It affected her increasing strong self-belief. Mentally, she felt better prepared for what would happen in the future and ready to look for solutions to make her more confident and optimistic. She also felt her ability to find solutions, deal with patients, follow the patient's fondness, and maintain the patient's comfort and feelings.

Based on the aspect of personal security, through a discussion session in the intervention, $\mathrm{P}_{2}$ regarded other participants as her new relatives rather than just new friends. She felt comfortable with other participants and they were seen as people who could give advice and provide useful solutions for her. For example, participant $3\left(\mathrm{P}_{3}\right)$ gave her information about how to find out the amount of water needed in an oxygen device and how to cook appropriately.

Based on the aspect of meaning and purpose, as a result of the intervention, she finally felt grateful because at least what the patient suffered from was merely a physical problem, and yet the patient was still able to communicate, discuss, and provide solutions. The aim of treating $\mathrm{P}_{2}$ was even broader, hoping the patient would get recovered physically and psychologically. $\mathrm{P}_{2}$ became more grateful for the psychological functions her patient still had.

As a result of the intervention, compared to the condition before the intervention when she stated her difficulty at number 4 , she stated it at number 2 .

\section{Participant 3}

Before the psychoeducational support group intervention was carried out, the participant 3 $\left(\mathrm{P}_{3}\right)$ was seen to have personal security and meaning and purpose that were quite good. Still, her aspect of strong self-belief was mediocre as 
was seen from both qualitative and quantitative data. The average score of her strong self-belief was lower compared to the scores of the other aspects.

Based on her initial strong self-belief, she was strong enough when the patient got cranky, but she felt less able to keep them company, assessing her ability at the score of 4 . She felt she was still lacking in providing care to the patient because she was still confused about how to manage the patient's diet and afraid of feeling guilty should something wrong happened.

$\mathrm{P}_{3}$ 's knowledge test score was 17 out of 30 questions, which was lower than the other participants. The time she started to do the test was not the same as that of the other participants. However, the researcher did not necessarily ask her to collect the test sheets immediately. The researcher waited for her to submit the sheet herself. She was seen glancing a few times when other participants began to submit their sheets, and she tried to follow other participants who had completed the test earlier.

As a result of the intervention, $\mathrm{P}_{3}$ 's strong selfbelief appeared to be increasing. She assessed her ability after going through the intervention was at the maximum score of 10 . Her improved ability could be seen in the way she served, following the discussion material 1 and 2 . She was able to pay attention to the patient following the material 2 . She loved the patient more and accepted it according to material 2. She was able to stay healthy while she took care of the patient.

During the intervention, $\mathrm{P}_{3}$ received some forms of emotional support. Through a process shared with fellow caregivers, she found out that the other caregivers had also experienced what she had. She asked them first several times whether they had also experienced what she had just shared with them. Through sharing experiences, she felt more energetic and more comfortable in treating the patient. It affected her increased personal security. She stated that having good new sisters made sharing experiences more energetic and treating the patient more comfortable.

Furthermore, she seemed to implement the tips of becoming a resilient caregiver by telling the truth to people close to her. After speaking to her children about the patient's condition, she felt calm and no longer sad because her children were supportive. They, for example, volunteered to escort the patient to the hemodialysis unit.

During the intervention, she was seen to get reinforcement from $\mathrm{P}_{2}$, who advised her to be grateful for the situation they were both in. She perceived her role as an obligation and a form of gratitude, pleasure, and pity for patients. Her sole objective was to make the patient get healthy again.

She stated that the intervention had changed her. Her caregiving to the patient was successful. Initially, she felt that he had not been quite successful. It was only $60 \%$ successful in treating the patient. Following the intervention, she felt she was $100 \%$ successful. This was consistent with the increase in the score of her resilience. Therefore, it could be concluded that psychoeducational support group interventions affected increasing participant 3's resilience.

\section{Participant 4}

Based on the qualitative data obtained before the psychoeducational support group intervention, participant $4\left(\mathrm{P}_{4}\right)$ explained that she seemed to have enough aspect of resilience. It was consistent with the quantitative data showing that her resilience score was in the high category, similarly, if viewed from the other aspects, even 
the highest among other participants. However, she still had problems.

P4 gained a score of 20 for the knowledge test. The new knowledge affected increasing her strong self-belief. After the intervention, she assessed that her ability increased by 2 points, from 7 to 9 .

After the intervention, she felt more comfortable viewing the aspect of personal security because she got informed about the other participants' experiences as caregivers. She regarded them as her relatives or family.

Based on the aspect of meaning and purpose, $\mathrm{P}_{4}$ got a deeper understanding of the meaning of the material presented and the other participants' shared experiences. It affected the emergence of a new meaning within her as she stated that she had perceived caregiving and a form of a mother's duty and compassion, also like a challenge and a spiritual implication that God has paved everyone's life path.

Viewed from the apparent behavior before the intervention, $\mathrm{P}_{4}$ stated that she stayed with the patient all the time; she even did not eat regularly and had enough sleep because she had to to stay awake when the patient had sleeping problems. Realizing the need for every caregiver to streamline their energy and the importance of maintaining physical and psychological health, she allowed the patient to do things that they could do and just watched them from a distance. Besides, she tried to eat regularly, sleep longer, and listen to music as a way to please herself.

Before the intervention, $\mathrm{P}_{4}$ stated that she had been already quite successful in treating the patient because she considered herself not complaining about carrying out the role. After the intervention, there was a change in the assessment of its success. She valued her success at a scale of $80 \%$.

\section{Participant 5}

Based on the qualitative data, participant 5 $\left(\mathrm{P}_{5}\right)$ seemed to have a good resilience aspect. This was also supported by the quantitative data scores of the aspects of resilience. Her personal security and the meaning and purpose were categorized as high, while her strong self-belief was moderate (upper limit). However, she did have physical and psychological problems before she received the intervention, (physical fatigue, sleep deprivation, uncontrolled eating, frequent recurrences of gastric ulcer, back pain, sadness due to the thought about her children who still needed a father, financially unreliable husband, anxiety, being irritated when the patient talked about death, and anger at the patient who breached health protocols).

$\mathrm{P}_{5}$ managed to obtain a cumulative score of 27 from the knowledge test. Information sharing affected increasing her strong self-belief. After the intervention, she scored herself 8, a 1-point increase. She also stated that the intervention carried out affected her mentally and physically. She felt she was able to channel her energy appropriately and felt stronger mentally. She became more convinced that she had to share the energy with others and this she discussed it with the patient's mother. Besides, because she was more able to accept the patient's condition, she became mentally stronger.

Based on her initial personal security aspect, she had her mother-in-law who was willing to help. Through the intervention process that could provide emotional support by sharing stories with other participants, she felt having friends with the same fate so that she got stronger physically and psychologically. The other participants shared similar situations where they had also received unpleasant treatment from their 
surroundings, but they suggested the ways to deal with it. She also felt relieved that she was able to tell her stories with fellow participants. With the other people who were not caregivers, it wouldn't be easy for her to share her feelings and experience. She assessed that the other participants paid attention to her and the patients by asking about the situation.

What is more, she managed to tell her mother-in-law about the way her husband had treated her in the past: she wished that the older woman could give mild reprimands to her ailing son to change his attitude to his wife. The patient was notoriously impatient and irritable. And the patient had become more considerate lately. He became sober and more patient.

$\mathrm{P}_{5}$ felt more fortunate than $\mathrm{P}_{4}$. She also felt grateful considering the patient's condition being not treated in a hospital like the other participants' patients. Thus, the intervention affected increasing her aspect of meaning and purpose. After the intervention, she could interpret the role as gratitude and take care of various things regarding the needs of the patient both in physical and psychological terms (preparing food, washing, planting). Her objective was more focused, specifically encouraging her patient.

Thanks to the intervention, she changed the way she assessed her success. Initially, she considered herself not quite successful in treating the patient because she did not do everything by herself; her family aided her. However, she seemed to experience some internal conflict. On the one hand, she felt she was successful when handling everything by herself, but on the other hand, she also felt that she could have fallen ill if she had handled everything on her own. With the information about the importance of managing energy by allowing others to help, she changed her success standard. She then considered herself $90 \%$ successful in treating the patient. After the intervention, she stated that she had successfully treated the patient as she had tried to do many things for the patient. The increase in success was also reflected in the quantitative data that showed an increase in the resilience score at 128 after the intervention.

\section{Discussion}

In general, each participant experienced positive changes. Through their participation in the psychoeducational support group intervention, they learned that from the previous treatments (physical and psychological), there were things still needing to be addressed. They increasingly understood that it was unlikely for the the patient to stop hemodialysis so that the standard of success had to be changed to the patient complying with the caregiver's instructions; understanding the use of problem-solving ways through paying attention first to the context of the problem; realizing the importance of maintaining physical and psychological health; being aware of the various future possibilities ; knowing how to communicate something to patients; knowing how to entertain themselves, and realizing that they were not alone in the situation requiring them to provide treatment for hemodialysis patients. Apart from their thoughts and feelings, the participants also experienced positive changes. They became more receptive to their conditions, mentally more prepared for future possibilities, more confident, more optimistic, calmer, less afraid of making mistakes, more enthusiastic, and more relieved.

Furthermore, based on the qualitative data, in general, all participants seemed to experience changes in their aspects of resilience, specifically 
in terms of personal security, strong self-belief, and meaning and purpose (Hooper, 2012). Brown (2004) reveals that the primary focus of the psychoeducational support group is to educate the subject about the existing conditions while paying attention to their emotional aspects.

Participants' personal security increased because of group support during the intervention. When individuals gain a strong sense of personal security, it means that they have an environment that loves them. The participants stated that they had new relatives or friends with whom they could share their caregiving experiences with. They showed that they felt comfortable with the on-going process within the group. During the discussion at each meeting, they could share their experiences as meaningful sources of information or new examples while at the same time providing a sense of togetherness as they were having the same condition of being a caregiver. Emotional support also came from each participant so that they managed to go through the difficult circumstances.

This was consistent with the Resilience Research Center (n.d.) explanation that there is a meaningful relationship between individuals, which includes social support and a positive role model that can affect their resilience.

Furthermore, it was seen that the participants' strong self-belief increased. A strong selfbelief means that there is strong self-confidence over personal strengths and competencies in an individual. Research data of participants selfassessment showed that their abilities increased based on their scaling before and after the intervention. The assessment was influenced by the material, especially material 1 , which contained information related to the disease and how to treat it. Material 2 contained the topic of resilience and how an individual can become a resilient caregiver of a chronic kidney disease patient. The variety of educational information is the focus of psychoeducational support group intervention. This finding agrees with one of the resilience factors listed in the resilience research centre (Resilience Research Center, n.d.), namely the existence of a positive outlook and confidence in one's personal strengths and abilities. It means that with the new material, individuals become more confident about their abilities to become more resilient.

The analysis of the resilience aspects based on the qualitative and quantitative data shows the aspect of strong self-belief showed the highest increase. Therefore, the psychoeducational support group had a positive effect on the participants' strong self-belief, which increased their resilience.

Likewise, it was found that participants' third aspect also changed. Meaning and purpose is the existence of an understanding of the meaning and purpose that directs an individual's efforts to growth and achievement. After the intervention, the participants gained new meanings, such as gratitude for their conditions, a sense of being needed by the patient, pleasure, pleasing the patient, encouraging the patient, and a form of challenge.

Another finding of this study was that the participants' meaning and purpose always had the highest mean value compared to the other aspects of resilience, both in pre-test and posttest. Besides, based on their personal interpretation, the participants discovered some spiritual implications, such as gratitude for the ongoing conditions and belief in God's presence, who rules everything. It is consistent with Elkins's spirituality component (in Desiana, 2008) namely 
the existence of a dimension of awareness of tragic events and a transcendence dimension in spirituality. Cavis (2015) states that spiritual and religious meanings can help individuals who experience difficult times to develop in a healing process. Research conducted by Cahyani and Akmal (2017) also showed that spirituality, which is interpreted as a person's struggle to achieve goals and undergo connectedness with oneself, other people, and transcendent forces, plays a significant role in resilience. The emergence of the spirituality theme could be associated with the locations where the participants were taken, namely religion-based hospitals. This study's spiritual meanings were related to the high spirituality seen in the hospitals' routine activities. It was consistent with the results of Hasanuddin's study (2014) which stated that hospital's regular activities such as Morning Prayer and religious lectures could make individuals confident of the transcendent power in the form of illness and recovery based on God's power.

The study conducted by Cartensen, Isaacowitzm, and Charlez (1999, in Snyder \& Lopez, 2002) discovered that older people are capable of perceiving higher meanings than the younger ones. Therefore, considering that the participants in this study were middle-aged adults, this affected the higher mean value of the meaning and purpose aspect compared to that of the other two aspects of resilience.

Furthermore, based on the results of the statistical tests that had been carried out, it was concluded that there was no difference between the results of the pre-test and those of the posttest using the resilience scale. Based on the descriptive analysis conducted on the resilience scores, there was an increase in the resilience scores of 3 participants and a decrease in 2 participants. Two participants, $\mathrm{P}_{2}$ and $\mathrm{P}_{4}$, who experienced a decrease in resilience score, were influenced by the patients' conditions before the post-test. $\mathrm{P}_{2}$ 's patients four days before the posttest had indigestion, while $\mathrm{P}_{4}$ 's patients were hospitalized three days before the post-test. The research done by Fadilla (2014) stated that the characteristics or conditions of the patients became the external factor of the emergence of anxiety in the caregivers. Anxiety on the caregivers' part could raise doubts when filling the scale.

Creswell and Creswell (2017) stated that one of the threats to internal validity is called regression. Regression is a condition when participants who have high scores are chosen to the subjects of a study. Their scores will very likely change during the study and may even decline to an average. The decrease occurred because $\mathrm{P}_{2}$ realized that many things can happen and may affect them personally. The more things the participants knew, the lower they would score in their self-assessment when filling in the post-test resilience scale.

However, seen from the interview results, there was an increase in the participants' assessment of their success in treating the patients. It was revealed that the difference in the difficulties in treating the patients before and after the intervention also decreased significantly.

Furthermore, although in the qualitative data generally, all the participants seemed to experience changes in the aspects of resilience, it was different from the quantitative data. The qualitative data showed an increase in the participants' resilience, while the quantitative data showed no significant change in the scores 
gained before and after the intervention. All the participants' scores of the resilience scale were in the high category before the intervention because there were stereotype factor answers. Azwar (2013) states that the scale items need to be made in a favourable and unfavourable direction to avoid stereotyping of answers. The participants whose attitude is consistent will realize that their answers are at one of continuum ends. For the next item of questions, they tend to place the answers following the existing patterns simply. Besides, following the research results by Widhiarso and Suhapti (2009) the initially high mean scores make it hard to reach optimum increase. It is called a ceiling effect in which participants, before being subjected to intervention have high mean scores to limit the possible increase.

In addition to the qualitative and quantitative data on resilience, there were supporting data obtained through a knowledge test in this study. The result of the knowledge test for each material indicated that the participants with higher education achieved the highest cumulative score compared to other participants. This was related to their ability to capture knowledge as discussed by Notoatmodjo (2003, in Muthmainnah, 2010) that the higher a person's level of education, the easier it is for them to understand information. On the other hand, the less education someone has, the harder it is for them to perceive new things. The participants who had higher education levels were more able to grasp information to gain a better result of knowledge test than the participants with lower levels of education.

\section{Conclusion}

It is concluded that psychoeducational support group has a positive effect on increasing the resilience of caregivers. Besides, psychoeducational support groups can significantly improve the perceptions of the ability to treat patients and reduce the level of difficulty in taking care of patients. Furthermore, strong self-belief increased significantly, which was due to a better understanding of chronic kidney disease and resilience. Collaborative activities in the group are also useful for improving personal security. The delivery of materials concerning chronic kidney disease and resilience and discussions among caregivers can improve the aspects of meaning and purpose. Besides, the patients' conditions are an external factor that can affect caregivers' resilience.

\section{Suggestion}

Findings of this study can be applied in similar disciplines or contexts. For example, this intervention can be used by clinical psychologists. Training of Trainers can be carried on by those who are willing to implement the findings of this study, with the addition of the related modules.

In hospitals with hemodialysis units, given the increasing number of patients, more caregivers need intervention. The said hospitals should implement this approach and improve the quality of the training materials to strengthen caregivers' empathy. This intervention must be performed regularly depending on the number of patients, perhaps on the same day as the patient's hemodialysis schedule, with a break in each session so that caregivers can see the patient. The sessions should be carried out in a private room adjacent to the hemodialysis room to maximize their benefits.

Future researchers on this topic should consider increasing the number of participants, and equalize the characteristics of the participants, use several measurements (time series 
Psychoeducational support group to the resilience of caregivers of chronic kidney disease patients ....

design), and it is also necessary to confirm the there is a discrepancy between quantitative data data obtained from the results of scaling in case and qualitative data.[]

\section{References}

American Psychological Association. (2016). The road to resilience. http://www.apa.org/helpcenter/road-resilience.aspx

Azwar, S. (2013). Penyusunan skala psikologi. Pustaka Pelajar.

Brown, N. W. (2004). Psychoeducational groups process and practice. New York: Brunner-Routledge.

Bukhori, B., Hassan, Z., Hadjar, I., \& Hidayah, R. (2017). The effect of sprituality and social support from the family toward final semester university students' resilience. Man in India, 97(19), 313-321.

Cahyani, Y. E., \& Akmal, S. Z. (2017). Peranan spiritualitas terhadap resiliensi pada mahasiswa yang sedang mengerjakan skripsi. Psikoislamedia: Jurnal Psikologi, 2(1), 32-41. https://doi.org/10.22373/psikoislamedia.v2i1.1822

Cavis, J. (2015). Is psychopathology the only outcome for female survivors of sexual trauma? The role of resilience in the healing of a survivor. Minnetonka: Adler Graduate School.

Chien, W. T. (2008). Effectiveness of psychoeducation and mutual support group program for family caregivers of Chinese people with schizophrenia. The Open Nursing Journal, 2, 28-39. https://doi.org/10.2174/1874434600802010028

Creswell, J. W., \& Creswell, J. D. (2017). Research design qualitative, quantitative, and mixed methods approaches. SAGE Publications, inc.

Desiana, K. (2008). Gambaran spiritualitas pada perawat Rumah Sakit Umum dr. Pirngadi Medan. Universitas Sumatra Utara.

Fadilla, L. (2014). Peran harapan dan resiliensi terhadap stres,kecemasan dan depresi pada caregiver penderita stroke. Universitas Islam Negeri Sultan Sarif Kasim Riau.

Family Caregiver Alliance. (2009). Caregiving. Caregiver.Org. https://www.caregiver.org/caregiving

Greeff, A. (2005). Resilience: Personal skills for effective learning. Bancyfelin: Crown House Publishing.

Harmell, A. L., Chattillion, E. A., Roepke, S. K., \& Mausbach, B. T. (2011). A review of the psychobiology of dementia caregiving: A focus on resilience factors. Current Psychiatry Reports, 13(3), 219-224. https://doi.org/10.1007/s11920-011-0187-1

Hasanuddin, R. J. B. (2014). Harapan sembuh pada penderita penyakit kronis. Universitas Negeri Makassar, Makassar.

Hébert, R., Lévesque, L., Vézina, J., Lavoie, J. P., Ducharme, F., Gendron, C., Préville, M., Voyer, L., \& Dubois, M. F. (2003). Efficacy of a psychoeducative group program for caregivers of demented persons living at home: A randomized controlled trial. Journals of Gerontology - Series B Psychological Sciences and Social Sciences, 58(1), 58-67. https://doi.org/10.1093/geronb/58.1.S58

Hooper, J. (2012). What children need to be happy, confident, and successful: Step by step positive psychology to help children flourish. Jessica Kingsley Publishers.

Indonesian Renal Registry. (2014). 7th Report of Indonesian Renal Registry.

Kahn, W. A. (2005). Holding fast: The struggle to create resilient caregiving organizations. BrunnerRoutledge. 
Lefley, H. P. (2009). A psychoeducational support group for serious mental illness. Journal for Specialists in Group Work, 34(4), 369-381. https://doi.org/10.1080/01933920903219094

Mansjoer, A. (2000). Kapita selekta kedokteran. EGC.

McCurry, S. M. (2006). When a family member has dementia: Steps to becoming a resilient caregiver. London: Praeger.

Merrill, D. M. (1997). Caring for elderly parents. Greenwood Publishing Group.

Muthmainnah, F. (2010). Faktor-faktor yang berhubungan dengan pengetahuan ibu dalam memberikan makanan pendamping air susu ibu di Puskesmas Pamulang 2010. UIN Syarif Hidayatullah Jakarta.

Navaie-Waliser, M., Feldman, P. H., Gould, D. A., Levine, C., Kuerbis, A. N., \& Donelan, K. (2002). When the caregiver needs care: The plight of vulnerable caregivers. American Journal of Public Health, 92(3), 409-413. https://doi.org/10.2105/ajph.92.3.409

Nevid, J. S., Rathus, S. A., \& Greene, B. (2005). Psikologi abnormal (R. Medya \& W. C. Kristiaji (Eds.); J. Murad (Trans.)). Erlangga.

Nuriyyatiningrum, N. A. H., \& Usri, K. (2017). Gambaran resiliensi pendamping pasien chronic kidney disease yang menjalani hemodialisa.

Posner, C. M., Wilson, K. G., Kral, M. J., Lander, S., \& Mcllwraith, R. D. (1992). Family psychoeducational support groups in schizophrenia. American Journal of Orthopsychiatry, 62(2), 206-218. https://doi.org/10.1037/h0079337

Resilience Research Center. (n.d.). A multidimensional model of resilience. Resilienceresearch.Org. Retrieved August 10, 2016, from http://resilienceresearch.org/about-the-rrc/ourapproach/16-a-multidimensional-model-of-resilience

Schoon, I. (2006). Risk and resilience adaptation in changing times. Cambrige University Press.

Schulz, R. (2000). Handbook on dementia caregiving. Springer Publishing Compani, Inc.

Sharma, N., Chakrabarti, S., \& Grover, S. (2016). Gender differences in caregiving among familycaregivers of people with mental illnesses. World Journal of Psychiatry, 6(1), 7-17. https://doi.org/10.5498/wjp.v6.i1.7

Smeltzer, S. C. O., \& Bare, B. G. (2003). Brunner and suddarth's textbook of medical-surgical nursing. Philadelphia: Lippincott Williams \& Wilkins.

Snyder, C. R., \& Lopez, S. J. (2002). Handbook of positive psychology. In Handbook of Positive Psychology. https://doi.org/10.1093/oxfordhb/9780195187243.001.0001

Widhiarso, W., \& Suhapti, R. (2009). Eksplorasi karakteristik item skala psikologis yang rentan terhadap tipuan respon. Jurnal Psikologi, 36(1), 73-91. https://doi.org/10.22146/jpsi.7905 